Article received on 27th January 2012 Article accepted on 27th February 2012

UDC: 785.7.087.6

78.071.1 Никодијевић М. 78.071.1 Лист Ф.

\author{
Jelena Novak*
}

\title{
POLITICS OF SADNESS: LITTLE FLOWER, REFRIGERATOR LORRY, DEATH AND SYMPHONIC TRADITION
}

\begin{abstract}
Marko Nikodijević's composition “cvetić, kućica.../la lugubre gondola: funeral music after franz liszt - in memoriam" (2009) is one of the intriguing examples of questioning music for orchestra and the problematization of its status today. The first part of the text offers some guide marks for contextualizing the piece from the composer's words in and about the score. The second part of the text traces particular compositional procedures and the relationship with Liszt's piece used as a palimpsest that might reveal meanings significant for understanding of Nikodijević's music, and offers conclusions about his and his piece's daring political, professional and artistic statements.
\end{abstract}

Keywords: Marko Nikodijević, symphonic music, funeral music, Franz Liszt, palimpsest

Апстракт: Композиција Марка Никодијевића “cvetić, kućica.../la lugubre gondola: funeral music after franz liszt - in memoriam” (2009) једна је од интригирајућих примера преиспитивања музике за оркестар и проблематизације њеног статуса данас. У првом делу текста ауторка, на основу композиторових речи и и око партитуре, предлаже одређена упутства за контекстуализацију композиције. Други део прати конкретне композиционе поступке и везе са Листовим делом, које, коришћено као палимпсест, може открити значења важна за разумевање Никодијевићеве музике, и закључује освртањем на смеле политичке, професионалне и уметничке исказе Никодијевића и његовог дела. Кључне речи: Марко Никодијевић, симфонијска музика, погребна музика, Франц Лист, палимпсест

* Author contact information: artina@beotel.net 
Writing music for the symphonic orchestra today confronts composers with a difficult task. Music for this ensemble has already been reinvented in so many ways that it becomes increasingly hard to further explore the limits of its world. Therefore, most often contemporary music for orchestra sooner or later presents the listener with conventions. The ideological structure that supports the hierarchy and social function of symphonic orchestras often detaches symphonic music from the contemporary media-oriented world, failing to rejuvenate its audience, among others. The paradox I see developing from this state of affairs is that despite significant budgets spent on the maintenance of large orchestras, the system of star soloists and conductors, repertory politics often tend to stagnate, firmly bound to some of the 'mainstream symphonic axes' (Bruckner-Mahler-Strauss, for example).

I take the composer's decision to write a new piece for the symphonic orchestra today as a statement of its own. I tend to understand it as his/her conviction that $\mathrm{s} /$ he has something to explain/ask/perform/do by or about music for orchestra that was not done before. In many cases, however, I am reassured, since the composer's decision to accept stereotypes of symphonic tradition often produce yet one more, unproblematic multiplication of conventional languages and procedures. In a lesser number of cases, composers seek the answers about the status and function of symphonic music today, and try to find a possible place for it in late capitalist Western society or elsewhere. Marko Nikodijević's composition "cvetić, kućica.../la lugubre gondola: funeral music after franz liszt - in memoriam" (2009) ${ }^{1}$ is one of the intriguing examples of questioning music for orchestra and the problematization of its status today. ${ }^{2}$ In the first part of the text I shall extract some guide marks for contextualizing the piece from the composer's words in and about the score. In the second part of the text I shall rely on particular composi-

\footnotetext{
${ }^{1}$ The composer insists on using the lower case in the titles of his compositions: "Lowercase is deflection from big (and impossible) narrative, consciousness that so called 'new music' is just one of subcultures of numerous musical traditions (recent as jazz, rock or techno or older as folklore music. Welcome to postmodernism". Marko Nikodijević in email conversation, January 26th, 2012.

${ }^{2}$ The composition was comissioned by Brandenburger Symphoniker Verein. It was premiered on 12 September, 2009 in Brandenburg, by the Brandenburger Symphoniker conducted by Michael Helmrath.This piece is already highly acclaimed. It won his author the prestigious Gaudeamus prize in 2010, awarded by the Gaudeamus Foundation in the Netherlands. Before that, the piece was announced to receive the Mokranjac prize for composition in Belgrade awarded by the Union of Composers of Serbia. But that prize was withdrawn for administrative reasons: the fact that the composer had received German citizenship and consequently gave up his Serbian citizenship made him ineligible for the prize. The composition also won the second prize at the Tansman Competition in 2010, in Poland.
} 
Novak, J.: Politics of Sadness: Little Flower, Refrigerator Lorry, Death ... (65-75)

tional procedures and the relationship with Liszt's piece used as a palimpsest that might reveal meanings significant for understanding Nikodijević's music. ${ }^{3}$

\section{Remediation}

The composition "cvetić, kućica..." is for a large orchestra. ${ }^{4}$ It lasts approximately 16 minutes. The score is written in $\mathrm{C}$ (sounding pitch) with the usual transpositions. It was composed in a unique way. Nikodijević took the recording of Liszt's La Lugubre Gondola no. 1 and worked with it, changing it electronically, stretching it, and compressing it and layering the results in many ways. When he was satisfied with the sound he had 'constructed', he transcribed the result for the orchestra. ${ }^{5}$ The conventional methodology of composing is problematized by this process. What is common is that composers sit with the instrument, playing their musical ideas, writing them down, while imagining the orchestration. Nikodijević, however first created the sound exactly how he wanted to hear it. Only after that did he go back to writing, trying to get the desired sound from another source, acoustic media - orchestra. In that process, numerous unconventional orchestration procedures took place, and the achieved sound result somewhat resembles electronic music. The reversal of the composer's attitude towards his achievement is different from the conventional. While in the conventional methodology of composing, composers often are not satisfied with the performers, who, it seems, rarely manage to fully create what the authors imagined, in this case, it seems like Nikodijević first satisfies his imagination (at least partly), by providing the exact sound he wanted to hear. Only after that, does he create the score, leaving it to the orchestra musicians in both his and their attempt to re-create what he already heard before.

As the composer notes, various features of the orchestra were affected by the intention to remediate the electronic music for orchestra. One of them is the strict indication of how the disposition of the orchestra members should look:

"The strings are seated in the German disposition, first violins and cellos to the left, second violins and violas to the right, with violins parallel to one another. Ideally, the three double bases are seated in the middle (in the last row with percussion or on a platform behind percussion, to enable the conductor's view over the orchestra). If this is not possible then the double bases are to the right. The piano and harp are seated in the middle of the orchestra, behind the violas and cellos. The piano is an

${ }^{3}$ For more details about composer's biography and worklist see: http://www.sikorski.de/ 5692/de/Nikodijević marko.html

${ }^{4}(3,2,2,2-2,2,2,1-\overline{3} \mathrm{Schl}$ (Pk, 7 C rot, gr.Tr, 2 hg.Bk, 7 Thai-Gong, Tam-t, G 1 [4 hg. Röhren], Glsp, Vibr), Harfe, Klav (verst. Pianino mit Supersordino), Streicher (8/6/4/4/3))

${ }^{5}$ From an e-mail conversation with Marko Nikodijević, January 26, 2012. 
instrument with practice pedal (supersordino), the instrument is lightly amplified to gain more sonic presence (not necessarily loudness), the exact amount of amplification depending on the general acoustics of the performance space. The microphone is to be positioned over the plucked strings (first octave), and the loudspeaker to be placed in front of the piano. ${ }^{6}$

The amount of details with which Nikodijevic arranges the structure of the sound source, itself speaks about the sensibility of the sound structure, and complexity of the composer's understanding of the sound space. Also, some players in the orchestra change the instruments:

Triangle choir - in the last section (indifferente, ma sempre in tempo) bass clarinet, basson, double bassoon, 2 horns and if possible 2 trombones and tuba play triangles. The triangles should ideally all be of different size, and struck with a soft wooden mallet (stick), with almost no attack only resonance. The tubular bells must be freely hanging and not in the usual stands (played always with soft vibraphone mallets). Percussion (except bass drum) and harp - always allow the instrument to resonate (unless otherwise indicated). ${ }^{7}$

The resonance required is also the consequence of transposing electronic music based on a piano recording, abundant with overtones and pedal. The composer draws attention to the constant presence of the 'sound fog' around the recognizable motives of Liszt's piece. He sees the 'sound fog' as a consequence of the pedal that presents the real sound mass on the recording, but also as the consequence of the other different artefacts that resulted from the procession of the recording. 8

Together with the set of specific playing techniques that I shall write about in the second part of the text, all these procedures imply an unconventional orchestra experience. As the composer himself claims, the above mentioned procedures are secondary characteristics resulting from the approach to the orchestra. According to Nikodijević, the orchestra is treated as electroacoustic media, and the harmonic language is inseparable from the orchestration, since they are both derived from the spirit of the sound synthesis. "(...) That is why the form of composition is similar to the form of techno music: layers of decentered loops meet each other at some 'cumulative points' only to be separated shortly after." 9

\footnotetext{
${ }^{6}$ Marko Nikodijević, "Cvetić, kućica.../ la lugubre gondola: funeral music for orchestra after franz liszt - in memoriam", score, Sikorski Musikverlage.

${ }^{7}$ Marko Nikodijević, "Cvetić, kućica.../ la lugubre gondola: funeral music for orchestra after franz liszt - in memoriam”, score, Sikorski Musikverlage.

${ }^{8}$ From an e-mail conversation with Marko Nikodijević, January 26, 2012.

${ }^{9}$ From an e-mail conversation with Marko Nikodijević, January 26, 2012.
} 
Novak, J.: Politics of Sadness: Little Flower, Refrigerator Lorry, Death ... (65-75)

\section{On Gondolas and Lorries}

The program note, written by the composer, relates the composition to the tradition of musical romanticism and its quest for answers about death, but also, and somewhat unexpectedly, places it in the political context of the turbulent years of Serbia in Milosević's time:

"Inspired by Venetian gondolas on which the dead were escorted to their final resting place, the composition is based entirely on Liszt's famous piano piece "La Lugubre Gondola I". The original is broken into fragments, compressed and stretched, shimmering like the layer traces which remain visible in a palimpsest. The title cvetić, kućica means 'little flower, little house' in Serbian, and describes a drawing in the notebook of a 5-year-old, Kosovo-Albanian girl whose body was found in a refrigerator lorry sunk in the Danube by Serbian police in 1999. The composition is dedicated to her memory". ${ }^{10}$

The motto of the composition that Nikodijević takes from Edgar Allan Poe's poem is also a reflection about death:

"While from a proud tower in the town

Death looks gigantically down"11

According to the piece's title, motto and program note, "cvetić, kućica..." is about death, grief and sadness.

Liszt's piano composition, to which Nikodijević refers, belongs to the last period of Liszt's creative opus, a period during which Liszt himself was increasingly interested in subjects related to death. In terms of musical language, this composer was looking for the ways of further developing and problematizing the harmonic structure of his pieces. It is noted that this composition was inspired by the Venetian funeral gondolas that Liszt observed in 1882 when he visited Richard Wagner in Venice. It was also implied that the piece could be understood as Liszt's farewell to Wagner, who died shortly after, on February $13^{\text {th }} 1883 .{ }^{12}$ Liszt's two late piano pieces - La Lugubre Gondola I (1882?) and La Lugubre Gondola II (1882) - evoke the funeral gondola that is commonly seen in Venice taking the coffin of the deceased along the canals towards the cemetery situated on the island in the Venice lagoon. Although Wagner was buried in Bayreuth, his coffin was taken in a gondola from the house on the Grand Canal in which he died, towards the train station in Venice, from where it was further escorted to Germany.

\footnotetext{
${ }^{10}$ Marko Nikodijević, “Cvetić, kućica.../ la lugubre gondola: funeral music for orchestra after franz liszt - in memoriam", score, Sikorski Musikverlage.

${ }^{11}$ Edgar Allan Poe, The City in the Sea.

${ }^{12}$ Philipp Jens Richardsen, The late piano works of Franz Liszt and their anticipation of musical ideas of the twentieth century, dissertation, University of California, Santa Barbara, p. 22-23.
} 
In addition to the tradition of musical romanticism, and Venetian burial practice, Nikodijević makes a striking parallel in relation to funeral gondolas. In the program note, he introduces the context of the crimes committed during Slobodan Milošević's regime in Serbia. The particular crime in question was the assassination of Kosovo Albanians. Nikodijević refers to the discovery of their bodies in the refrigerator lorry that was later found in one of the Serbian lakes. He dedicates the piece to the memory of an unnamed Albanian girl, who was one of the victims. Knowing about the practice of Venetian funeral gondolas, suddenly 'intercepted' with a morbid reminder of the refrigerator lorry filled with human bodies, Nikodijević makes a grieving, and ironic remark. If death in Venice was treated with dignity, and funeral gondolas sailed elegantly, with respect for the deceased taking the last journey to their resting place, in Milosević's Serbia, respect for the dead, and also respect for life, were not common practice. The arrow that Nikodijević throws with this morbid analogy between the Venetian funeral gondola and the Serbian refrigerator lorry is the arrow of sadness, protest and disgust.

This is also the point where the composer enters the sphere of the political. The Serbian-born, and now naturalized German, Nikodijević, might have had a chance to feel uneasy when his artistic work was presented outside of Serbia. The context of Milosević's years with wars, crimes, and violence was for a long time among the regular news coming from this country. That context often overshadowed everything else that was coming from there at the time. In the sphere of the arts in Serbia, this period brought a number of artworks that dealt with the conflicts and crimes of the ex-Yugoslav states and its peoples.

I understand Nikodijević's program note also as a kind of critique of the obsessive, realistic portrayal of Milošević's era. The way I read it, what he does with "cvetić, kućica..." tells the listener: look, I come from Serbia, where some kill innocent people and put them in refrigerator lorries, throwing their bodies to decay in the lakes. But, look, there is something else there. It is my music. And even when my music is supposed to speak about Serbian horrors, it fails to do so. This music goes beyond the political realm of Serbia, it indeed 'speaks' about death, grief, sadness, loss, but in a more general way, is able to address various situations and practices. It is about the depth of death, about its eternity, about the void, about the huge emptiness that remains after a life is ended. And indeed, Nikodijević himself states: "What I didn't want is to speak about horror in the language of horror. I didn't want an onomatopoeia of horror. I wanted all the musical onomatopoeia's energy to be one of a spilled sea aquarelle". ${ }^{13}$

The concept of the 9/11 memorial opened last year in New York strikingly problematized similar issues. It is at the same time a monument in memory and

${ }^{13}$ From an e-mail conversation with Marko Nikodijević, January 2012. 
Novak, J.: Politics of Sadness: Little Flower, Refrigerator Lorry, Death ... (65-75)

honor of those who were killed in the terrorist attacks, and a sad reminder of the destructive forces, and the hopelessness before the void of death. I could draw a parallel here to what Nikodijević does with this composition. The composition could be perceived as a sound monument to the people who were killed by the regime in Serbia, a sorrowful reminder of how evil and destruction assumed power, and also it is the expression of helplessness faced with the loss of a life that will never be retrieved. At the same time, Nikodijević does not remain only at the level of political connotations in Serbia. He takes the subject of death, one of the favorite themes elaborated by the artist of romanticism, and problematizes it further by deconstructing the romantic musical language, including its symphonic tradition.

\section{Palimpsest}

When referring to Liszt's piece, Nikodijević mentions the notion of the palimpsest. The palimpsest is a "a parchment or other writing-material written upon twice, the original writing having been erased or rubbed out to make place for the second; a manuscript in which a later writing is written over an effaced earlier writing." 14 Thus, the composer's intention is to use Liszt's piece as a kind of faded pad, in which he will make room for his own writing. But, Nikodijević does not use Liszt's score in that process; he uses the audio recording of the composition. ${ }^{15}$

Liszt's La Lugubre Gondola no. 1 is a short and reduced piano piece in which the composer explores the tonal harmonic language by the extensive use of chromatics. While the left hand part brings a constant flow of quavers, the right hand part introduces a dark colored, gloomy melody, starting with leaps of the sixths, and then developing in descending chromatic movement. The composition has the general form of a variation (A, A1, A2), in which each new appearance of the sorrowful theme, in different tonal centers, does not bring a brighter atmosphere. ${ }^{16}$

\footnotetext{
${ }^{14}$ According to the Oxford English Dictionary Second Edition on CD-ROM (v. 4.0.0.2)

${ }^{15}$ As I have reminded earlier in my text about Nikodijević's composition Chambres de Ténèbres/Tombeau de Claude Vivier this author often refers to the music of other composers. For example: György Ligeti, Igor Stravinsky, Olivier Messiaen (music box/selbstportrait mit ligeti und strawinsky /und messiaen ist auch dabei/, 2000 - 2001/2003, revision 2006), Carlo Gesualdo da Venosa (gesualdo transcriptions I - objekt/raum, 2004, gesualdo abschrift/antiphon super o vos omnes, 2011), or Claude Vivier in his 2005 piece. Jelena Novak, "A Queer Protocol of Homage: Chambres de Ténèbres/Tombeau de Claude Vivier by Marko Nikodijević", New Sound, International Magazine for Music no. 29, pp. 67-76.

Available online: http://www.newsound.org.rs/clanci_eng/8.\%20Jelena\%20Novak.pdf, Accessed: January $15^{\text {th }}, 2012$.

${ }^{16}$ For a detailed formal analysis of Liszt's piece, see: Philipp Jens Richardsen, The late piano works of Franz Liszt and their anticipation of musical ideas of the twentieth century, dissertation, University of California, Santa Barbara, p. 22-47.
} 
It is as if Liszt looks into the eyes of death from different perspectives. And what he sees is always similar: the inexorable force of Thanatos is at the same time gloomy and invincible, it pulls life down, "gigantically down" as Poe would have written, to the infinite void. According to Petersen, La Lugubre Gondola no. 1 is an example of 'grundgestalt', a way of constant reshaping the basic element of the musical composition that brings coherence to the whole. The form of the piece and the analysis of the motives could easily confirm this claim.

Nikodijević treated Liszt's score like a kind of 'archive' of sorrowful motives. He imported Liszt's motives in his composition randomly, remediated them, developed them, deconstructed them, disfigured them, listened to them again and again, carefully, to finally see if and how they would reflect sadness in the new environment. In my previously quoted text, I mentioned the procedure of granular sythesis that Nikodijević used. ${ }^{17}$ The way he uses Liszt's materials in this piece follows the same methodology. The number of characteristic motives are taken as 'grains' that 'germinate in different timbres, a different hierarchy, making a new sound realm that originates from familiar sources.

Now, when I analyze Liszt's composition parallel with Nikodijević's piece, it looks like each time when I listen to it, I hear something new, some new relation to Liszt's model. Before analyzing Liszt, the experience of listening to "little flower..." was much more straightforward. When hearing it 'through' Liszt's piece, it becomes enlightened with an infinite number of possibilities. The process went into reverse, too: now I also listen La Lugubre Gondola 1 through Nikodijević's 'rework' of it, and that becomes a much more profound experience than it was before.

I believe, however, that it is not essential for understanding Nikodijević's composition to meticulously trace fragments of Liszt's piece in it. What I shall try to trace is the gloomy atmosphere that the composer 'imports' from Liszt's composition and develops it further. That atmosphere is realized through various kinds of subtle sound textures that are not very common for orchestral writing. "My treatment of the orchestra looks like functional sound synthesis, not in the digital, but in the instrumental domain. It is not a simple orchestral painting of the layers. A great part of the softness and transparency of the sound originates from an almost complete omission of the doubling", the composer writes. ${ }^{18}$

\footnotetext{
${ }^{17}$ Jelena Novak, “A Queer Protocol of Homage: Chambres de Ténèbres/Tombeau de Claude Vivier by Marko Nikodijević", New Sound, International Magazine for Music No. 29, pp. 61-63.

Available online: http://www.newsound.org.rs/clanci_eng/8.\%20Jelena\%20Novak.pdf, Accessed: January $15^{\text {th }}, 2012$.

${ }^{18}$ From and e-mail conversation with Marko Nikodijević, January 26, 2012.
} 
Novak, J.: Politics of Sadness: Little Flower, Refrigerator Lorry, Death ... (65-75)

Some of these effects are created with the help of unusual playing techniques that all aim at contributing towards the subtle, soft sound of the orchestra. But, that subtlety bears a surprisingly rich range of nuances, and they make this sound world extremely delicate and different from what is usually heard in orchestral concerts. The example which illustrates what I previously stated is the way in which Nikodijević explains some of the playing techniques he requires from the strings:

Flaut. - flautato, fast bow with light pressure, veiled, mysterious sonority

SP - sul ponticello (overtone sound with the fundamental clearly present)

$\mathrm{mSP}$ - molto sul ponticello (extreme overtone sound with the fundamental barely present)

bartok pizzicato

sea-gull effect in strings is continuous glissando with the spacing between fingers kept constant. The partial jumps occur of their own accord

pan flute effect on the violas is achieved playing on the IVth string, bowing flautato as near the left hand as possible ${ }^{19}$

When I first listened to "cvetić, kućica..." I did so without the score. At its very beginning, the piano, played "pizz. col plettro, sonoro" by plucking on the strings brings a gloomy, simple, varied motive. And, at first I couldn't realize which instrument was playing. The score, of course, explained 'the mystery'. And at that moment, I immediately imagined the cartoon-like figure of Liszt, plucking the strings of an upright piano. "There must be some irony in this", I thought. And indeed, to make the sound of a piano unrecognizable in that way reveals some of Nikodijević's general intentions at the very beginning of the composition. As he reconfigured the sound of the piano, he also reconfigured the whole composition he was referring to. I remember this detail of not recognizing the sound of the instrument because it happened a few more times that I had to 'investigate' the origin of the sound that I was hearing. Dynamics that predominantly move in various modes of piano, from $p$ to pppp do not work to facilitate those kinds of investigations. On the contrary, it makes the listener over-attentive in the effort to register changes that might unfold. The politics of this listening erases the ideology by redefining the expectations of what is heard in the orchestra. It does not take the music for granted; the composer does not allow that to happen.

At the beginning of the second large part of the composition (bar 37), all the way to the end, the piano part that was by then bringing a simple single-part melody plucked on the strings, started bringing 'signals' consisting of the pulsation of the single chord (c-es-g-as) in the left hand part, con supersordino sempre al fine, always in different constellations of triplets, with an irregular frequency of pauses in

\footnotetext{
${ }^{19}$ Marko Nikodijević, “cvetić, kućica.../ la lugubre gondola: funeral music for orchestra after franz liszt - in memoriam", score, Sikorski Musikverlage.
} 
between, starting first $\mathbf{m f}$ and then decrescending, and gradually, later as sfff, each time, until the appearance of the next 'signal'. According to the composer's own words, this 'signal' represents the waves. ${ }^{20}$ And indeed, it sounds like the everlasting, somewhat irregular, wave movement. This mimesis is joined, towards the end of the composition, by another one: the croaking of seagulls. Since the parallel between gonodolas and lorries is present throughout the piece, this picture evoking seagulls circling over the water and croaking, could be imagined as the sound reference to sailing death, whether it is a gondola, or a lorry. The signal of waves is constant, and resurfaces from all the other layers of sounds. Through it, I hear all the other materials. In bar 104, the signal of the waves is joined with bright resonating timbres of crotales and other percussions. The seagull glissandi of strings float above those chords that become more frequent towards the end of the piece. The sound of the 'sea aquarelle' engulfs all the rest. Only silence remains. But that silence is not empty. It is filled with memories, thoughts, questions, hopes, fears, unrest. And maybe above all, it is filled with sounds, rich sounds that I hear again and again, imagining my own version of remembrance. These are the sounds that I now imagine, but that I couldn't have imagined in the orchestra before.

To return to the beginning of the text, I understand the composition "cvetić, kućica..." as the composer's statement in several ways. Politically, it is the composer's outspoken conviction of the horrors committed by Milošević's regime. Also, it is the work of an East European composer (at the time), who reflects in the piece about the socio-political situation in his country (among others), presenting it to the Western art world, while confronting its expectations. In the musical domain, I perceive it as the composer's questioning of the ways how and why music for orchestra today should still be written, specifically when its status and function is examined parallel with the infinite possibilities offered by electronic music. Finally, bearing in mind the way the piece is composed, "cvetić, kućica..." questions the status and function of the composer today, too. Marko Nikodijević deals with all the above mentioned challenges sharply and confidently, offering intriguing, relevant and brave answers. That is why this composition holds a significant place on the map of contemporary 'new music'.

\section{REFERENCES}

Jens Richardsen, Philipp, The late piano works of Franz Liszt and their anticipation of musical ideas of the twentieth century, dissertation, University of California, Santa Barbara, 22-23.

Novak, Jelena, 'A Queer Protocol Of Homage Chambres de ténèbres/Tombeau de Claude Vivier by Marko Nikodijević', New Sound, 29, I/2007, 59-68.

${ }^{20}$ From an e-mail conversation with Marko Nikodijević, January 26, 2012. 


\section{Example 1}

With kind permission MUSIKVERLAG HANS SIKORSKI GMBH \& CO. KG, Hamburg

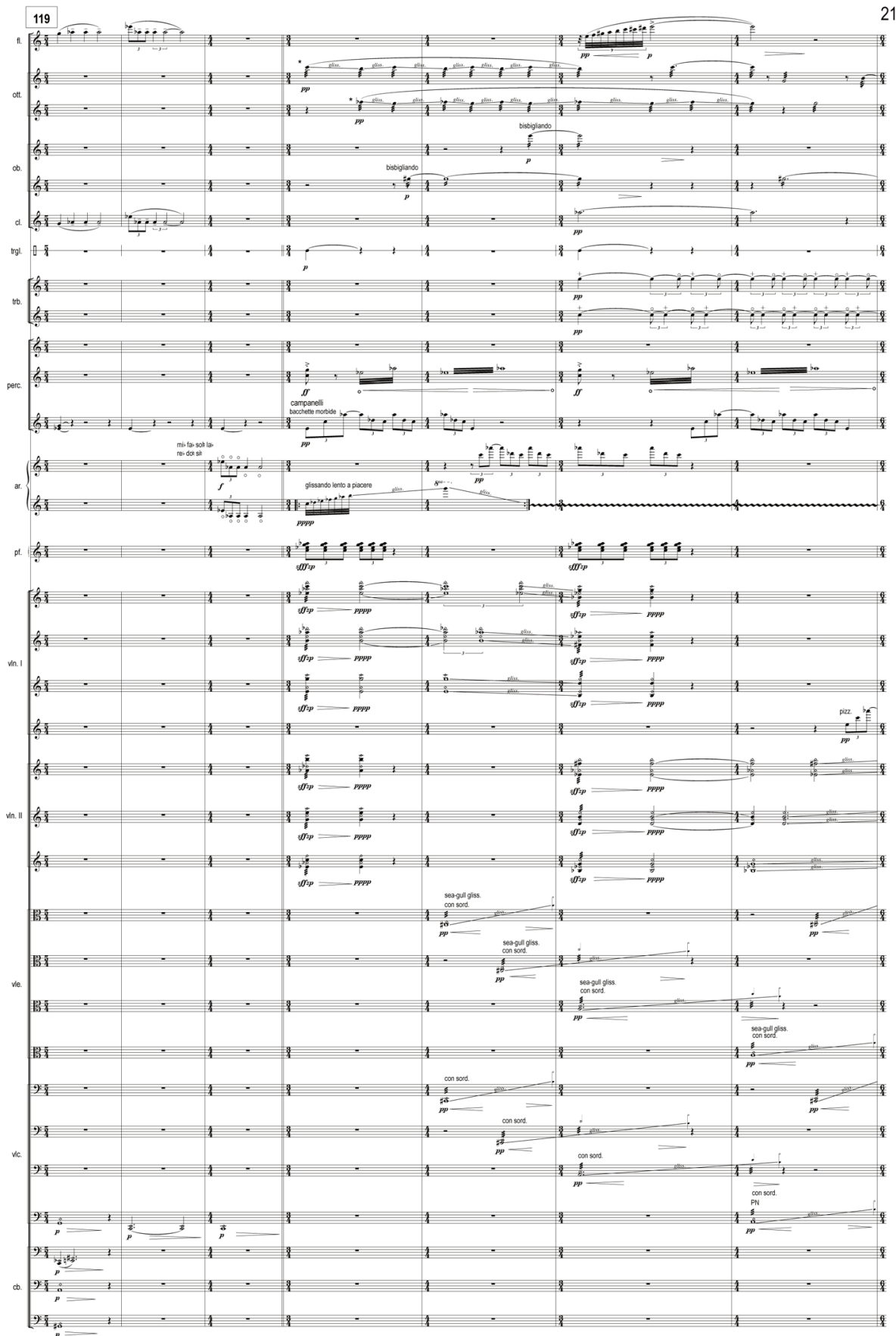

